This is an Accepted Manuscript of an article published by Taylor \& Francis in the Journal of Peasant Studies on 09 Jun 2014, available online: http://www.tandfonline.com/doi/abs/10.1080/03066150.2014.918958\#.VeCmsfmqqko. To cite this article: Mamonova, N., \& Visser, O. (2014). State marionettes, phantom organisations or genuine movements? The paradoxical emergence of rural social movements in postsocialist Russia. Journal of Peasant Studies, 41(4), 491-516.

\title{
State marionettes, phantom organisations, or genuine movements? The paradoxical emergence of rural social movements in post-socialist Russia ${ }^{1}$
}

\author{
Natalia Mamonova and Oane Visser
}

\begin{abstract}
Of all the rural social movements in the world, those in post-socialist Russia are considered to be among the weakest ones. Nevertheless, triggered by the neo-liberal reforms in the countryside, state attention to agriculture, and rising land conflicts, new social movement organisations with a strong political orientation are emerging in Russia today. However, this sudden burst of civil activity raises questions about how genuine and independent the emerged organisations are. Our research shows that many rural movements, agricultural associations, farm unions, and rural political parties lack constituency, are supporting the status quo, and/or actually counterfeits (what we call 'phantom movement organisations'). With this analysis we aim to explain the nature of social movements in the post-Soviet countryside and offer an original contribution to the theory on and practice of rural social movements.
\end{abstract}

Keywords: rural social movement organisations, state-society relations, rural development, land grabbing, Russia, post-socialism

\section{Introduction ${ }^{2}$}

Faced with the issues of rural poverty, globalisation of food markets, land grabbing, and other contemporary rural problems, rural people all over the world have organised themselves in social movements in order to challenge the negative effects of the neoliberal development. Land rights movements of Latin America and Africa, peasant organisations in Asia, rural community associations and radical farmers’ groups in Europe, North America and Australia work at village, regional, national and international levels to make sure that the voice of the rural people is heard at every level of decision-making (Woods 2008).

The Russian rural population, on the contrary, is rather passive in defending its own interests and is not eager to engage in collective practices of contestation. The rural society in Russia was traditionally seen as conservative, politically apathetic, and phenomenally patient and endurant (Sanukov 1993, Breshko-Breshkovskaya 2007). The Russian villagers’ reluctance to engage in overt collective protests

\footnotetext{
${ }^{1}$ This is an Accepted Manuscript of an article published by Taylor \& Francis in the Journal of Peasant Studies on 09 Jun 2014, available online: http://www.tandfonline.com/doi/abs/10.1080/03066150.2014.918958\#.VeCmsfmqqko. To cite this article: Mamonova, N., \& Visser, O. (2014). State marionettes, phantom organisations or genuine movements? The paradoxical emergence of rural social movements in post-socialist Russia. Journal of Peasant Studies, 41(4), 491-516.

2 The research for this paper benefited from a grant provided by the Land academy sponsored by the Dutch Ministry of Agricultural, Economics and Innovation, as well as from a grant from the Land Deal Politics Initiative (LDPI). We thank Jun Borras, Max Spoor, Gemma ter Haar, Kees Jansen, Marc Edelman, and the reviewers for comments on earlier versions.
} 
This is an Accepted Manuscript of an article published by Taylor \& Francis in the Journal of Peasant Studies on 09 Jun 2014, available online: http://www.tandfonline.com/doi/abs/10.1080/03066150.2014.918958\#.VeCmsfmqqko. To cite this article: Mamonova, N., \& Visser, O. (2014). State marionettes, phantom organisations or genuine movements? The paradoxical emergence of rural social movements in post-socialist Russia. Journal of Peasant Studies, 41(4), 491-516.

is often explained by the legacy of the pre-revolutionary commune system in rural areas, which was based on mutual support and, therefore, reduced the vulnerability of individual households to adverse developments (Atkinson 1983, Male 1971); 70 years of socialism, when the expression of disagreement with governmental actions was at least heavily frowned upon, with serious protest leading to deportation in the labour camps of the Gulag during Stalin's reign, or prosecution in later periods (Visser 2010); demographic characteristics such as ageing and the low density of rural population (see Perrie (1972) about rural mobilisation during the Russian Revolution, and Visser (2010) on the present-day mobilisation problems); the contemporary authoritarian regime of Putin, which is able to repress, divide, and demobilize undesired public protests.

In such circumstances, when the rural population is unwilling to engage in political actions and when there is little space for contestations, the significant increase of rural social movement organisations that have emerged in the last decade might be seen as surprising. Based on our web search and interviews, we observed that nine out of ten rural civil organisations, agricultural associations, farm unions, and rural political parties were formed and registered in the period 2000-2012. ${ }^{3}$ These claim to protect the interests of rural dwellers, fight against land grabbing and inequality in the countryside, and create a favourable climate for development of agricultural entrepreneurship in Russia. This sudden burst of civil activities has coincided with the economic recovery in agriculture, the increase in state subsidies to rural development projects, the rise of agro-investments, and the large-scale land acquisitions.

Therefore, the question about the origins and actual aims of the contemporary rural social movement constitute an important topic. What is behind this sudden burst of civil activities and to what extent does it reflect concerns among the rural population? Is it the civil society's reaction to the neoliberal developments in the countryside? If so, then why did these rural social movement organisations not appear after the demise of the Soviet regime in 1991, or during the agrarian crisis of the post-socialist transformation period when there were 'open moments' for political actions? Why did they only emerge in the early/mid-2000s? Do they truly protect the interests of their members, are they state 'marionettes', or are they established for another reason? Given the tendencies in post-Soviet Russia towards the creation of a quasi- and/or guided civil society (Daucé 2010, Fröhlich 2012), the autonomy (or embeddedness) of these civil organisations and their real aims are essential in understanding the contemporary rural social movement in Russia.

\footnotetext{
${ }^{3}$ This finding was based on data collected from secondary sources and through in-depth interviews with representatives of rural social movement organisations. In total, 30 RSMOs and agrarian political parties operating in Russia were analysed for this research. The short summary is presented in Table 1. For a complete dataset please contact the authors.
} 
This is an Accepted Manuscript of an article published by Taylor \& Francis in the Journal of Peasant Studies on 09 Jun 2014, available online: http://www.tandfonline.com/doi/abs/10.1080/03066150.2014.918958\#.VeCmsfmqqko. To cite this article: Mamonova, N., \& Visser, O. (2014). State marionettes, phantom organisations or genuine movements? The paradoxical emergence of rural social movements in post-socialist Russia. Journal of Peasant Studies, 41(4), 491-516.

For the purposes of this research we define rural social movement organisations (hereafter referred to as RSMOs) as formal civil (non-profit) organizations which are established by or on behalf of rural dwellers, have specific programs, policies, and practices, but share a common goal of representing the interests of the rural population at a local, regional and/or national levels, and therefore constitute a rural social movement. RSMOs thus differ from the broad understanding of civil or social organizations, the latter of which may or may not have a function in terms of representing their members politically.

This research is the first comprehensive study of RSMOs in post-Soviet Russia. Previous studies on post-Soviet rural politics have focused on the response strategies of the rural population to the state's agrarian reforms, and have prioritised informal practices, social networks and hidden protests over formal organisations (Wegren 2005, Tauger 2005, Humphrey 2002). However, more formalised collective action through social organisations can provide resources and an institutional base to rural movements, structure mass protest, and carry the movements' values and goals during periods of low mobilisation (Zald and McCarthy 1987, Taylor 1989). Studies of institutionalised civil organisations in post-Soviet Russia, which have been carried out on contemporary urban social movements, show the unexpected forms of collective action that can be discerned within the limited political opportunity structure $^{4}$, once one goes beyond liberal and statist models of state-society relations (Fröhlich 2012, Henry 2006, 2010, Chebankova 2012, Kulmala 2011). These studies demonstrate that movements (i.e. environmental, animal rights, and disability movements) often cooperate with the state while at the same time being able to preserve their autonomy. This position diverges from earlier academic works on the post-Soviet social movements, which saw Russian civil society as underdeveloped and suppressed by an authoritarian regime (Hale 2002, Janoski 1998, Salamon and Anheier 1998). The turn from viewing civil society as a counterforce to the state to viewing it as a collaborator with the state defines the recent changes in the state-society relation studies in Russia and globally (Kröger 2011).

This article follows the emerging understanding of state-society relations and takes the limited political opportunity structure as the starting point. We analyse RSMOs in the 'Russian climate', where civil society organisations have close relations with the state while sometimes also contributing to the 'war of position', i.e. creating alternative institutions and alternative intellectual resources within the existing society (Fröhlich 2012, Chebankova 2012). Although we build our arguments upon many assumptions drawn from contemporary urban social movement studies, we acknowledge the

\footnotetext{
${ }^{4}$ The political opportunity structure is defined here as the relative openness or closeness of the institutionalised political system, influenced by state-elite alignments and the state’s capacity and propensity for repression (Tarrow 1998).
} 
This is an Accepted Manuscript of an article published by Taylor \& Francis in the Journal of Peasant Studies on 09 Jun 2014, available online: http://www.tandfonline.com/doi/abs/10.1080/03066150.2014.918958\#.VeCmsfmqqko. To cite this article: Mamonova, N., \& Visser, O. (2014). State marionettes, phantom organisations or genuine movements? The paradoxical emergence of rural social movements in post-socialist Russia. Journal of Peasant Studies, 41(4), 491-516.

existence of rural specificities, such as the aversion of rural dwellers to open group actions and highly politicized issues of land tenure in agricultural investments.

The paper questions several assumptions in the theories on social movements and state-society relations, and aims to provide new insights into rural political actions. It contributes to understanding the Russian civil society from the angle of RSMOs and broadens our view on civil contentious politics in rural areas in post-Soviet contexts in particular and under (semi)authoritarian regimes in general.

We structure our analysis as follows. In the next (second) section we discuss the post-Soviet land reform and the potential 'open moments' for collective political actions which appeared at the time. Further, we introduce the current situation, characterised by the rise of large-scale land acquisitions, agricultural investments, and increased state support of agriculture and rural development projects. This allows us to understand the context in which RSMOs have emerged. In the third section we present our classification of RSMOs and discuss their state embedding and organisational affiliations, their connection with the local population, as well as the genuineness (as opposed to a counterfeit existence) of these organisations. We distinguish five types of RSMOs: grassroots organizations, professionalized organizations, government affiliates, politically oriented organisations/parties, and phantom movements. Finally, in section four we conclude with our preliminary findings, questions for discussion and deliberation, and an outline of some of our thoughts for further analysis and theoretical interpretation. As such, we aim to set an agenda for the study of RSMOs in Russia and the post-Soviet area at large (e.g. Ukraine and Kazakhstan), with a relevance extending to (semi)authoritarian and post-socialist contexts at a broader level.

This paper is largely based on qualitative data derived from in-depth interviews with representatives of seven RSMOs and two political agrarian parties which emerged from RSMOs. These interviews were conducted by the first author in March 2011 in the Moscow region. In addition, this research benefits from interviews with local civil activists, local government officials, and large-scale agricultural investors conducted by the first author in the Moscow region in 2010 - 2013, and field research of the second author in the countryside of Rostov and Pskov regions in the early 2000s. Data was further obtained from web-pages of social movements and political parties, as well as from statistical sources of the Russian Ministry of Justice, Rosstat, and the Register of Public Organisations in Russia.

\section{Post-socialist transformations in the countryside and 'open moments' for emergence of social movement}

\subsection{The land reform and harsh transition period}


This is an Accepted Manuscript of an article published by Taylor \& Francis in the Journal of Peasant Studies on 09 Jun 2014, available online: http://www.tandfonline.com/doi/abs/10.1080/03066150.2014.918958\#.VeCmsfmqqko. To cite this article: Mamonova, N., \& Visser, O. (2014). State marionettes, phantom organisations or genuine movements? The paradoxical emergence of rural social movements in post-socialist Russia. Journal of Peasant Studies, 41(4), 491-516.

After the collapse of the Soviet Union in 1991, Russia embarked on a course of reforms (which Goodman (2003) called 'shock therapy'), with the ultimate goal of preventing the return to socialism. The de-collectivisation of agriculture was pursued through the privatisation of collective farmland. Kolkhozy and sovkhozy (collective and state farm enterprises), which possessed the major part of the agricultural land in the Soviet era, were forced to distribute their farmland by means of share-based certificates to their former employees. In such a way, the new Russian government wanted to create a system of small and medium commercial family farming in the country. However, due to the absence of financial resources and extension services, the existence of fragmented and dysfunctional markets and institutions, and the rural dwellers' unwillingness to leave the collectives, the majority of land recipients did not become private farmers (Visser and Spoor 2011, Wegren 2005). Instead, land became accumulated in the hands of former kolkhoz/sovkhoz chairmen (or outside investors), who convinced land recipients to invest their land (and property) shares in the reorganised farm enterprises in order to preserve the integrity of large-scale production. As Spoor et al. (2012) argued, the land reform did not fundamentally change de facto land ownership. The kolkhozy and sovkhozy were transformed into private large farm enterprises (LFEs), while a large part of the rural population continued to practice subsistence farming on their household plots. The private family farm sector that was envisaged in the early 1990s only emerged to a limited extent. ${ }^{5}$

The shift from a centralized to a market-oriented economy in the countryside was accompanied by price liberalisation and rising prices for agricultural inputs; the reduction of state support to agriculture, leading to the bankruptcy of many farm enterprises and growing unemployment; and the limitation or termination of the social functions provided by LFEs, which were formerly the responsibilities of kolkhozy and sovkhozy. All these factors have negatively affected life in rural areas. The post-Soviet transition period was characterised by the ruralisation of poverty. The monetary income of rural residents accounted for one half of urban incomes per capita in late 1990s. The peak of rural poverty was in $1999^{6}$, when $73.1 \%$ of rural dwellers had incomes lower than the subsistence level (Independent Institute for Social Policy 2002). Many of the rural dwellers, especially the young

\footnotetext{
${ }^{5}$ In 2010 there were 261.7 thousands of peasant-farms, which cultivated $11,4 \%$ of the agricultural land and contributed around $8 \%$ of the gross agricultural product in Russia. For comparison: more than 16 million rural households, while possessing only $5 \%$ of agricultural land, produce $45 \%$ of the gross agricultural product in Russia. The rest is produced by large-scale agricultural companies, which control the largest share of Russian farmland and produce nearly half of the farm products produced in Russia.

${ }^{6}$ However, a long-term series of surveys conducted by O'Brien et al. (2011) indicated the poverty rate was $49.5 \%$ in the 1999, while the peak of rural poverty occurred in 1993 when $69 \%$ of the rural population had incomes lower than the subsistence level. The difference in numbers can be explained by various techniques used for defining income and subsistence levels. In both cases, these numbers indicate the significant poverty levels in rural areas during the early transition period.
} 
This is an Accepted Manuscript of an article published by Taylor \& Francis in the Journal of Peasant Studies on 09 Jun 2014, available online: http://www.tandfonline.com/doi/abs/10.1080/03066150.2014.918958\#.VeCmsfmqqko. To cite this article: Mamonova, N., \& Visser, O. (2014). State marionettes, phantom organisations or genuine movements? The paradoxical emergence of rural social movements in post-socialist Russia. Journal of Peasant Studies, 41(4), 491-516.

people, 'voted with their feet' and moved to cities. Those who remained in the villages experienced a declining quality of life and increasing social problems.

According to Gourevitch (1986), this situation should have become the 'open moment' for political actions. Gourevitch believed that crises can open the political system to new challenges and alternative policies, and create opportunities for mobilization within a sector. Furthermore, the early post-Soviet period (1991-2000) was characterised by democratisation of the society, expressed in strengthening freedom of speech and freedom of associations, which enlarged the political opportunity structure in the country. However, the civil society organisations that emerged at that time were largely urban, and many of them existed only on paper. Others were generally insignificant in terms of members (at most a few thousand people), organisationally amorphous, or lacked clear programs (Osokina 2009).

An important reason for the absence of open bottom-up mobilisation and resistance at that time is the fact that almost every rural family possessed a household plot ( 0.2 ha on average). The production of potatoes and vegetables on these land plots guaranteed the survival of rural population in times of crisis (cf. Ries 2009, also for urban plot holders). Faced with economic difficulties such as wage arrears, rural dwellers did not collectively protest, but resorted to their household plots.

Another reason for the weak rural mobilisation is the demographic situation in the countryside. Nearly $20 \%$ of the rural population is older than 60 (Rosstat 2013). Moreover, Russia faces a crisis of rural depopulation: 22\% of rural settlements have less than 10 inhabitants, and $8 \%$ of villages are abandoned. The average density of the rural population in Russia is about two people per square kilometre (Yermolayeva 2010). The dispersed and aged rural population in Russia is not conducive to mobilisation.

Resistance did exist, but it was (and remains) mainly hidden. Nikulin (2003, 2010) considers villagers' gossiping, stealing, and foot-dragging to be forms of covert unorganised protest against LFEs, which fall into the category of 'everyday resistance' and 'weapons of the weak', as described by Scott (1985). However, theft at the LFEs is in many cases better qualified as a continuation of the Soviet principle 'everything is collective, everything is mine'7 (Panchenko et al. 2012, Humphrey 1983) and an additional source of subsistence than an intentional act of disagreement.

The best known rural social organisation which emerged at that time was (and is) AKKOR (Russian Association of Farmers and Agricultural Cooperatives). It was established top-down by an informal

\footnotetext{
${ }^{7}$ In the Soviet Union, stealing from collective farms was institutionalized. Humphrey (1983) discovered that the Soviet villagers used the 'word theft to refer only to stealing from one another' (ibid, 136). People presented pilfering at the farm as 'recovering things that were rightfully theirs, either because they'd worked on those things (harvested corn, pulled potatoes, or collected fruit) for inadequate pay or because they had once owned the land for growing these things and they were not getting enough to live on' (Humphrey 1983, 136). For an account of how foot dragging and mediocre work was institutionalised at collective farms see Nove (1973).
} 
This is an Accepted Manuscript of an article published by Taylor \& Francis in the Journal of Peasant Studies on 09 Jun 2014, available online: http://www.tandfonline.com/doi/abs/10.1080/03066150.2014.918958\#.VeCmsfmqqko. To cite this article: Mamonova, N., \& Visser, O. (2014). State marionettes, phantom organisations or genuine movements? The paradoxical emergence of rural social movements in post-socialist Russia. Journal of Peasant Studies, 41(4), 491-516.

order of the Soviet Ministry of Agriculture in 1990, when the first leasehold family farms started to emerge (Kopoteva 2012). At that time, government subsidies and credits for private family farms were allocated via AKKOR, which gave it a great deal of power. After the subsidies to AKKOR were reduced, the projects on the ground to support farmers were curtailed, while lobbying among, and cooperating with, governmental bodies were maintained, if not intensified. This association will be discussed in more detail later in this paper.

Another representative of the rural population during the early transition period was Agrarnaya Partiya Rossii (Agrarian Party of Russia). While not officially communist, it displayed many similarities with socialist ideologies. Created top-down, it did not have close links with the rural population, and lobbied the state on behalf of large collective farms. Makarkin (2004) refers to the party as 'a collection of Soviet-type rural functionaries, who struggled to slow down the pace of disappearance of collective agriculture' (ibid, 1). In 2009, Agrarnaya Partiya Rossii merged with United Russia and disappeared. ${ }^{8}$

For a long time these two top-down created organisations were the only ones to deal with rural issues in Russia.

\subsection{Rise of interest in land and agriculture and the appearance of RSMOs}

The situation has changed since the early/mid 2000s - the time of the Putin regime and economic recovery in agriculture. The Russian government turned its attention back to agriculture and revitalized the process of agrarian reforms, although now aimed at the development of large-scale industrial farming. The new Land Code (2001) aimed to modify property rights. It was followed by the adoption of the law 'On Agricultural Land Transactions' in 2002, which legitimised land transactions. This marked the establishment of an open land market in Russia and the commodification of farmland. Spurred by instability on financial markets, global food crisis, and the large supply and low cost of Russian farmland, many domestic and foreign ${ }^{9}$ investors became interested in Russian agriculture and started to acquire farmland (Visser 2013). The land rush was accompanied by the reinforcement of large-scale mono-crop farming and, especially in sub-urban and fertile agricultural regions, the

\footnotetext{
${ }^{8}$ The Agrarian Party of Russia re-emerged in 2012. Its re-emergence was caused by initiatives of some of its members who did not want to continue the consolidation with United Russia. The newly emerged party refused the former left-wing ideology of agrarian socialism and moved to centrism. Currently, the party represents the interests of the agrarian elite and supports large-scale strong agricultural producers. We will not study this organisation in detail as it does not represent the interests of the rural population.

${ }^{9}$ Foreigners are not officially allowed to acquire agricultural land in Russia. However, they do so by means of their Russian subsidiaries, which are considered Russian domestic companies by the Russian law.
} 
This is an Accepted Manuscript of an article published by Taylor \& Francis in the Journal of Peasant Studies on 09 Jun 2014, available online: http://www.tandfonline.com/doi/abs/10.1080/03066150.2014.918958\#.VeCmsfmqqko. To cite this article: Mamonova, N., \& Visser, O. (2014). State marionettes, phantom organisations or genuine movements? The paradoxical emergence of rural social movements in post-socialist Russia. Journal of Peasant Studies, 41(4), 491-516.

violation of the local communities' rights, i.e. the features that allowed Visser and Spoor (2011) to call this process land grabbing. ${ }^{10}$ Many villagers lost their rights to the land plots distributed during the first stage of the land reform. Land grabbing was carried out through different schemes ranging from buying up land share certificates at a very low price from each landholder to acquiring entire collective farm enterprises through forging statutory documents and bribing chairmen and local authorities ( $c f$. Visser et al. 2012 on legal, semi-legal and illegal land deals). This land rush resulted in the enlargement of LFEs and their incorporation in agroholdings, which control the whole agricultural value chain. ${ }^{11}$

Since the early 2000s, the state has stimulated agriculture through a range of instruments such as a debt restructuring programme, the establishment of a state-financed agricultural bank, subsidised crop insurance programmes, simplified and lowered taxes on agriculture, and subsidised loans for capital investment (Wegren 2007, 517). Whereas in the 1990s the state support for the agricultural sector was sharply curtailed, it has markedly increased under Putin (Shagaida 2012). Not only did agricultural business receive state attention, but many federal rural development programmes were also recently launched by the Russian government in order to improve the socio-economic situation in the villages. ${ }^{12}$ At the same time, local governments often remain underfunded, and their development projects are largely dependent on the corporate social responsibility initiatives of LFEs, which provide significantly less support for the social infrastructure than their collective predecessors. Overall, however, during the Putin era the economic and infrastructural decline in many rural areas was halted and in some cases reversed.

As a result of overall economic recovery and the inflow of private and state money in the countryside, the poverty rate fell to $25.4 \%$ in 2003, further falling to $15.4 \%$ in 2006 (O'Brien et al. 2011). An extensive study by O’Brien et al. $(2011,24)$ shows that rural dwellers became less depressed and more satisfied with their incomes and their country, while their satisfaction with life in their village communities declined.

\footnotetext{
${ }^{10}$ Land grabbing is the large-scale acquisition of land or land-related rights and resources by a corporate, non-profit or public buyer for the purposes of resource extraction geared towards external consumers (whether external simply means off-site or foreign) (White et al. 2012). For more about land grabbing in Russia see Visser and Spoor (2011), Visser et al. (2012). The latter shows that land acquisitions take many forms, from deals within the framework of the law, to clearly illegal deals. See Visser (2013) for a critical examination of the Russian 'land rush' which markedly slowed down from 2009 onwards.

${ }^{11}$ Many LFEs in suburban areas (especially those located close to Moscow and St.Petersburg) were artificially bankrupted and the status of their lands was transformed into land for construction purposes. Investment in land for (sub)urban development brings quick and high profits.

12 For example, The Federal Programs: 'Social Development of the Village Until 2012, 2013, 2014', 'Sustainable Development of Rural Areas, 2014-2017 and for the Period Until 2020', and 'The National Priority Project for the Development of an Agro-Industrial Complex' (launched in 2006).
} 
This is an Accepted Manuscript of an article published by Taylor \& Francis in the Journal of Peasant Studies on 09 Jun 2014, available online: http://www.tandfonline.com/doi/abs/10.1080/03066150.2014.918958\#.VeCmsfmqqko. To cite this article: Mamonova, N., \& Visser, O. (2014). State marionettes, phantom organisations or genuine movements? The paradoxical emergence of rural social movements in post-socialist Russia. Journal of Peasant Studies, 41(4), 491-516.

Along with the socio-economic improvements in Russia, the last decade is also characterised by the contraction of the political opportunity structure. After Putin's rise to power in 2000, the process of democratisation that set in during the early 1990s turned into the direction of a 'guided democracy', with a growing influence of the state on the political arena. Effective opposition was curtailed in many ways. The entrance levels for new parties were raised, several bureaucratic hurdles were created, and the media, having become increasingly state-controlled, ignored or negatively portrayed opposition forces. Out of fear for the penetration of Western values and financial and organisational support that might stimulate protests and revolts similar to the colour revolutions in Ukraine and Georgia, the Russian state imposed restrictions on the activities of foreign NGOs and social organisations with foreign funds (Ostroukh 2010).

The constitutional 'right to disagree' has failed to move beyond the letter of the law in contemporary Russia. The state's hostility towards criticism is often expressed in legal restrictions on collective actions, such as limiting the locations available for pickets and demonstrations (Politgazeta 2012). Formally, the legal system offers the population quite a lot of opportunities to resolve civil disputes in courts (Jacobsson and Saxonberg 2012). However, when the dissent is related to a highly politicised issue such as land grabbing, the courts seem not to work in favour of the rural poor (Visser et al. 2012).

Despite all these constraints, the last decade is also characterised by an increase in the number of RSMOs. To what extent do these organisations respond to this declining satisfaction of life in village communities? Do they protect the interests and rights of rural dwellers in land disputes, or do they benefit from financial flows from the state budgets and domestic and foreign land investments? And how do the recovery of agriculture, and on the other hand the limited political opportunity structure, influence their emergence? Below we provide an analysis of contemporary RSMOs, and their relations with the state and the rural population.

\section{Rural social movement organisations in Russia}

In mapping the current RSMOs in Russia, we build on the categorisation of the social movement organisations into (1) grassroots organizations, (2) professionalized organizations, and (3) government affiliates, as developed by Henry (2006) in her study of the environmental movement in Russia. Additionally, we include: (4) politically oriented organisations, and (5) phantom movement organisations, in order to capture the main types of actors working with rural issues (see Table 1). Different groups of RSMOs are oriented toward different actors within the Russian political and economic environments and tend to pursue different varieties of civil activism. However, the 
This is an Accepted Manuscript of an article published by Taylor \& Francis in the Journal of Peasant Studies on 09 Jun 2014, available online: http://www.tandfonline.com/doi/abs/10.1080/03066150.2014.918958\#.VeCmsfmqqko. To cite this article: Mamonova, N., \& Visser, O. (2014). State marionettes, phantom organisations or genuine movements? The paradoxical emergence of rural social movements in post-socialist Russia. Journal of Peasant Studies, 41(4), 491-516.

adherence to a particular organisational type is not static: one type of RSMOs may transform into another over time.

Table 1 clearly shows the state-embedding of the majority of RSMOs. Classic social movement studies contended that movements have to choose between autonomy and subordination to the state (Meyer 2004). However, recent studies on state-society relations have demonstrated that movements can be more efficient if they collaborate with the state, while keeping space to protest (Abers 2000, Dagnino 2002, Auritzer and Wampler 2004, Dagnino et al. 2006). Chebankova (2012) argues that civil society organisations in Russia have to choose close relations with the state in order to pursue their politics. The majority of RSMOs are connected to the presidential party Edinaya Rossiya (United Russia). This connection guarantees access to necessary resources for RSMOs' operations (the possibility to raise funds, participate in state rural development programmes, and informational support), as well political space for their activities. ${ }^{13}$ Vasily Vershinin, one of the leaders of the social organisation Agrarii Rossii, calls the state-RSMOs relations 'a system of the trough'. He asserted that:

Where the trough is, there are those members. When the $\mathrm{CPSU}^{14}$ was in power, they were next to that party. Then we had a party called Choice of Russia, then Our Home - Russia, then something else, and then United Russia... And this entire crowd has been running from one party to another. Their integrity, their political orientation [is] worth nothing. Where the "trough" is, there is a possibility of grabbing. Thus, they all are there. ${ }^{15}$

The convergence of the state with RSMOs is often mutual: social organisations gain resources and access; the state gains a firm control and the possibility to use civil society as an instrument to improve state governance (Richter 2009, 42).

The popular expression of a Costa-Rican movement leader: 'there are two ways to kill an organisation, with repression or with money', used by Edelman $(1999,165)$ in his book Peasants Against Globalisation, is also applicable to the Russian case. Along with legitimate control, the state sponsors the social activities of the majority of RSMOs. Furthermore, the state establishes state-financed social organisations such as GONGOS (Government-Operated Nongovernmental Organisations), which, in fact, are an extension of the state apparatus. Many RSMOs have representatives in GONGOs.

There are other financial sources available for RSMOs (such as entrepreneurial activities, donations, membership fees); however, they often generate insignificant revenues, thus, limiting the scope of

\footnotetext{
${ }^{13}$ The Russian state attempts to repress any forms of opposition in the country. Any organisation which does not share the political approach of Edinaya Rossiya has a limited possibility to exist legally in Russia.

${ }^{14}$ Communist Party of the Soviet Union

${ }^{15}$ Interview conducted in March 2011, in Moscow.
} 
This is an Accepted Manuscript of an article published by Taylor \& Francis in the Journal of Peasant Studies on 09 Jun 2014, available online: http://www.tandfonline.com/doi/abs/10.1080/03066150.2014.918958\#.VeCmsfmqqko. To cite this article: Mamonova, N., \& Visser, O. (2014). State marionettes, phantom organisations or genuine movements? The paradoxical emergence of rural social movements in post-socialist Russia. Journal of Peasant Studies, 41(4), 491-516.

organisational activities. Dependence of RSMOs on domestic donors leads to embeddedness with domestic elites, whose interests do not always reflect the interests of the rural population.

While various other Russian social movement organisations (environmental movements, for example) joined the global network of movements and transnational organisations in the 1990s, making them part of the larger global process (Tysiachniouk 2010, Henry 2006, 2010), RSMOs in Russia remain isolated from transnational movements. ${ }^{16}$ In the past few years of the Putin regime, cooperation with international donors and foreign NGOs has been increasingly limited by the state's protectionist policy; therefore, an inflow of foreign concepts such as food sovereignty and the idealisation of the 'peasant way of life' as promoted by, for instance, Western or Latin-American rural movements, is nearly absent in Russian rural social settings.

It is remarkable that the connection between RSMOs and the rural population is often vague. The closest relations with rural dwellers are observed in the case of (semi-)institutionalised grassroots organisations, which mobilise people for collective actions. Others have only indirect ties with the rural population (through local authority offices and informational support centres in rural areas), or no ties at all.

In the next subsections we examine typical representatives of government affiliates, grassroots organizations, politically oriented organisations, and phantom movement organisations. We do not discuss professionalised organisations separately, because they are often embedded in other institutionalised organisations and have a tendency to fall into a category of phantom movement organisations.

\footnotetext{
${ }^{16}$ When the authors tried to forge a connection between the Krestyanskiy Front movement with La Via Campesina, the leadership of the former showed no interest in collaboration, explaining it through the on-going depeasantisation of the Russian countryside and the lack of rural dwellers who would share peasant values and a desire for food sovereignty and land ownership. The recent study by Spoor et al. (2013) deals with the lack of a discourse of food sovereignty among Russian villagers and the inability of the rural population to see their small-scale subsidiary farming as an alternative to large-scale industrial agriculture. However, the disconnection from international movements is not only caused by the discourse among the Russian rural population or the decisions of the RSMOs' leadership. The state prevents the internationalisation of social movement organisations. Furthermore, the Russian state is currently actively blocking some of the already internationalized social movements, such as RAIPON (Russian Association of Indigenous Peoples of the North), which faced the introduction of a ban in November 2012.
} 


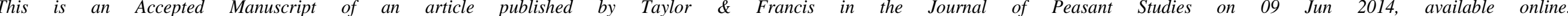

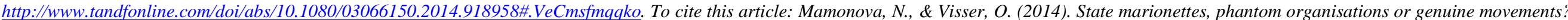
The paradoxical emergence of rural social movements in post-socialist Russia. Journal of Peasant Studies, 41(4), 491-516.

Table 1. Characteristics of Organisational Types within Russia’s Rural Social Movement ${ }^{17}$

\begin{tabular}{|c|c|c|c|c|c|}
\hline & $\begin{array}{l}\text { (Semi-)institutionalised grassroots } \\
\text { organizations }\end{array}$ & Professionalized organizations & Government affiliates & $\begin{array}{l}\text { Politically oriented organisations/ } \\
\text { parties }\end{array}$ & Phantom movement organisations \\
\hline Goals & $\begin{array}{l}\text { Resolve local land disputes (often } \\
\text { related to land grabbing) }\end{array}$ & $\begin{array}{l}\text { Gather groups of similar interests, } \\
\text { informational support and } \\
\text { facilitation of their activities }\end{array}$ & Implement state programmes & $\begin{array}{l}\text { Political representation of rural } \\
\text { population, however, often used as an } \\
\text { access to 'Big Politics' }\end{array}$ & $\begin{array}{l}\text { Represent the interests of its creators/ fulfil } \\
\text { promises of the parent-association/get access to } \\
\text { particular information or networks }\end{array}$ \\
\hline Target group & $\begin{array}{l}\text { Former kolkhoz' and sovkhoz' } \\
\text { employees (land shareholders) }\end{array}$ & $\begin{array}{l}\text { Special interest groups (gardeners, } \\
\text { ogorodniks, fishers, etc.) }\end{array}$ & $\begin{array}{l}\text { Commercial farmers, agro- } \\
\text { companies, rural population }\end{array}$ & Rural and urban population & $\begin{array}{l}\text { Sub-groups of rural population (youth, women) } \\
\text { or rural (urban) population in general/in a } \\
\text { particular region }\end{array}$ \\
\hline Methods & $\begin{array}{l}\text { Demonstrations, pickets, recourse to } \\
\text { courts }\end{array}$ & $\begin{array}{l}\text { Lobbying the state, informational } \\
\text { support to their members }\end{array}$ & $\begin{array}{l}\text { Cooperation with the state, } \\
\text { informational support to their } \\
\text { members }\end{array}$ & $\begin{array}{l}\text { Networking with politicians inside } \\
\text { parliament }\end{array}$ & Participation at conferences, social events \\
\hline Scope & All-Russian & All-Russian & All-Russian & All-Russian & Local/All-Russian \\
\hline Level of activism & Active & Moderately active & Active & Moderately active & Focal activism/Passive \\
\hline $\begin{array}{l}\text { Organisational } \\
\text { affiliations }\end{array}$ & $\begin{array}{l}\text { With political parties (i.e. social- } \\
\text { liberal party Yabloko, social- } \\
\text { democratic party Spravedlivaya } \\
\text { Rossiya), and with other grassroots } \\
\text { organisations }\end{array}$ & $\begin{array}{l}\text { Are often members of Government } \\
\text { Affiliates }\end{array}$ & With the United Russia, GONGOs & With United Russia & $\begin{array}{l}\text { With local authority or political leaders /as a } \\
\text { subsidiary of a larger social organisation or } \\
\text { political party }\end{array}$ \\
\hline $\begin{array}{l}\text { Connection to local } \\
\text { population }\end{array}$ & $\begin{array}{l}\text { Interpersonal connections, social } \\
\text { networks }\end{array}$ & $\begin{array}{l}\text { Membership networks, not directly } \\
\text { connected }\end{array}$ & $\begin{array}{l}\text { Governmental networks, not directly } \\
\text { connected }\end{array}$ & $\begin{array}{l}\text { Through social organisations, not } \\
\text { directly connected }\end{array}$ & Membership networks, not directly connected \\
\hline State embeddedness & Partial autonomy & Embedded & Embedded & Embedded & $\begin{array}{l}\text { Embedded in the state via the parent- } \\
\text { organisation }\end{array}$ \\
\hline Source of finance & $\begin{array}{l}\text { Sponsorship by private actors (i.e. } \\
\text { businessmen, politicians), } \\
\text { entrepreneurial activities }\end{array}$ & $\begin{array}{l}\text { Small membership fees, state } \\
\text { support }\end{array}$ & State support & $\begin{array}{l}\text { Entrepreneurial activities, sponsorship } \\
\text { by private actors (i.e. businessmen, } \\
\text { politicians), membership fees }\end{array}$ & Difficult to define/unknown \\
\hline Sample & $\begin{array}{l}\text { Krestyanskiy Front (Peasant Front), } \\
\text { Narodniy Front v Zaschitu Russkoi Zemli } \\
\text { (The Peoples Front of Russian Land } \\
\text { Defence), Nasha Zemlia (Our Land), Sovet } \\
\text { Initsiativnih Grupp (The Council of the } \\
\text { action teams for the rights of land } \\
\text { shareholders) }\end{array}$ & $\begin{array}{l}\text { Soyuz Sadovodov Rossii (Union of } \\
\text { Gardeners of Russia), Soyuz } \\
\text { Arendatorov I Zemlepolzovateley } \\
\text { (Union of Tenants and Land Users), } \\
\text { Ob'edinenie Sadovodov (Union of } \\
\text { Gardeners), Soyuz Ribolovetskih } \\
\text { Kolkhozov Rossii (Union of Fishing } \\
\text { Collective Farms of Russia) }\end{array}$ & $\begin{array}{l}\text { AKKOR (Russian Farmers' and } \\
\text { Agricultural Cooperatives' Association), } \\
\text { Rossiyskoe Agrarnoe Dvizhenie RAD } \\
\text { (All-Russian social organisation Russian } \\
\text { Agrarian Movement RAD), Rossiyskiy } \\
\text { Zemelniy Soyuz (All-Russian social } \\
\text { organisation Russian Land Union) }\end{array}$ & $\begin{array}{l}\text { Agrarii Rossii (Agrarians of Russia), } \\
\text { Selskaya Rossiya (Rural Russia), } \\
\text { Agrarnaya Partiya Rossii (Agrarian Party } \\
\text { of Russia), Ob'edinennaya Agro- } \\
\text { Promyshlennaya Partiya Rossii (United } \\
\text { Agro-Industrial Party of Russia), } \\
\text { Vozzozhdeniye Agrarnoy Rossii (Russian } \\
\text { agricultural revival) }\end{array}$ & $\begin{array}{l}\text { Selskaya Rossiya (Rural Russia), Rossiysky Soyuz } \\
\text { Selskih Zhenschin (Russian Union of Rural Women), } \\
\text { Dvizhenie Selskih Zhenschin Rossii (Movement of } \\
\text { Rural Women of Russia), Molodezhnoe Krilo Partii } \\
\text { Agrarii Rossii (Youth Wing of the party Agrarians of } \\
\text { Russia), Rossiyskiy Soyuz Selskoy Molodezhi (Russian } \\
\text { Union of Rural Youth), Selskaya Molodezh (Rural } \\
\text { Youth) }\end{array}$ \\
\hline
\end{tabular}

17 The table is developed based on the analysis of 30 RSMOs and agrarian political parties operating in Russia. The data was acquired from various internet sources and in-depth interviews with representatives of the analysed organisations during fieldwork in 2010-2011. For a complete dataset please contact the authors. 
This is an Accepted Manuscript of an article published by Taylor \& Francis in the Journal of Peasant Studies on 09 Jun 2014, available online: http://www.tandfonline.com/doi/abs/10.1080/03066150.2014.918958\#.VeCmsfmqqko. To cite this article: Mamonova, N., \& Visser, O. (2014). State marionettes, phantom organisations or genuine movements? The paradoxical emergence of rural social movements in postsocialist Russia. Journal of Peasant Studies, 41(4), 491-516.

\section{Government affiliates}

The typical representative of government affiliates is AKKOR (Russian Association of Farmers and Agricultural Cooperatives). We have introduced this RSMO earlier in this paper. The state-embedding of this organisation is observed throughout its history from its establishment in 1990 by an informal order of the Soviet Ministry of Agriculture, for purposes of government subsidies and credit allocation for emerging private family farms. Later, when the state support to farmers was curtailed, AKKOR intensified lobbying among, and cooperating with governmental bodies.

AKKOR participated in the Duma elections with different blocks (depending on what was the leading party at that time: in 1993 with Choice of Russia, in 1994 with Our home - Russia, and in 2010 with United Russia in developing the party's programme). The words of Vershinin, quoted above, are suitable: '...this entire crowd has been running from one party to another. Their integrity, their political orientation is worth nothing. Where the "trough” is, there is a possibility of grabbing...'

Representatives of AKKOR, however, insist that this state-embedding helps 'the Association to lobby more effectively farmers' interests, to make amendments to laws and to achieve acceptance of the important decisions for [the] peasantry in Russian regions' (in Kopoteva 2012, 47). Indeed, AKKOR developed and lobbied for the inclusion of the 'Russian farmer' programme in United Russia's political agenda in 2010. AKKOR's active participation in government meetings drew the authorities attention to the problems of small-scale farming, which led to the initiation of several state programmes oriented towards rural development. ${ }^{18}$

However, small-scale farmers themselves experience a decline of support from AKKOR. During fieldwork by Visser (2010) among 45 private farmers in Rostov and Pskov, which were among the more active ones in the region, it appeared that in the early 2000s only a few of them were members of AKKOR. In 2010, farmers of the Altai region appealed to president Medvedev in an open letter, complaining that AKKOR did not fulfil its direct task of protecting their interests (Information Agency Regnun Novosti 2010). Alexandr Gusev, a farmer from the Deulino village in the Moscow region, said in an interview about the help of AKKOR:

In order to help farmers, there is a need to be politically independent and unbiased and to have the courage to say a word against Putin's government. And they [AKKOR] do not have this, unfortunately. ${ }^{19}$

Indeed, we could not find any indication that AKKOR voiced different views to the official United Russia and Kremlin line ( $c f$. Kopoteva 2012). The state-embedding of AKKOR is also indicated by an interview with Tamara Semenova, a leader of the rural social movement Krestyanskiy Front:

\footnotetext{
${ }^{18}$ Information from the website of AKKOR: www.akkor.ru. Accessed 14 April 2013

${ }^{19}$ Interview conducted in village Deulino, the Sergiev Posad district, the Moscow region, April 2013.
} 
This is an Accepted Manuscript of an article published by Taylor \& Francis in the Journal of Peasant Studies on 09 Jun 2014, available online: http://www.tandfonline.com/doi/abs/10.1080/03066150.2014.918958\#.VeCmsfmqqko. To cite this article: Mamonova, N., \& Visser, O. (2014). State marionettes, phantom organisations or genuine movements? The paradoxical emergence of rural social movements in post-socialist Russia. Journal of Peasant Studies, 41(4), 491-516.

I think AKKOR has somehow moved away from people... private farmers and rural population in general... AKKOR went into the officialdom, like all those agrarian parties which had been created and created and dissolved in United Russia. ${ }^{20} 21$

Although, the state-embedding gives the organisation an opportunity to pursue its activities, it decreases its autonomy and creates a gap between it and the rural population. The Russian state incorporates many RSMOs in order to create 'state marionettes' that support the current national agricultural and rural development policy, thus, reinforcing state power.

\section{Grassroots organisations}

The prominent representative of grassroots social movement organisations is the Interregional Social Movement Krestyanskiy Front (Peasant Front). It stands for roughly the opposite of government affiliates in terms of organisation and approach to the state-society relations. Whereas the majority of state-embedded social organisations are established top-down, Krestyanskiy Front emerged from the village level. Starting with the cooperation of several rural dwellers deprived of their land shares in 2005, Krestyanskiy Front now accounts for about 25,000 members in Russia. It aims to defend the rights of former collective farm workers and other small land owners who lost their lands due to illegal/semi-legal land acquisitions (Visser and Spoor 2011).

The Front's leaders assert their claims through approved channels and use the regime's policies and legitimating myths to justify their defiance. As a partly institutionalized form of contention, the Russian anti-land-grab social movement organizes public events such as meetings, pickets, and rallies within the legal framework. Through these events, it draws the attention of federal, regional and local authorities to the dispossession of rural dwellers and their property rights violation as a result of land grabbing. Krestyanskiy Front represents its members in courts and fights against land raiders by demonstrating in front of their offices, and requesting statutory documents and public explanations. Due to the efforts of Krestyanskiy Front, hundreds of rural dwellers were compensated for lost land plots (Visser et al. 2012).

Tamara Semenova, one of the leaders of Krestyanskiy Front, describes her personal story of fighting land grabbing:

In the Soviet period our farm enterprise was called sovkhoz Gorki-2; now it is Agrocomplex Gorki-2,

Ltd. It is located on the most expensive land in the Moscow region - Rublevka, Zhukovka, Kolchuga, and

Razdory. These days many oligarchs and nouveaux riches have houses there. Our director, a former

\footnotetext{
${ }^{20}$ Interview conducted in March 2011, in Moscow.

${ }^{21}$ Our own experiences in dealing with AKKOR suggest decreased accessibility and increased bureaucratization. For more than half a year, our research group has been trying to obtain an interview with the head of AKKOR, to no avail.
} 
This is an Accepted Manuscript of an article published by Taylor \& Francis in the Journal of Peasant Studies on 09 Jun 2014, available online: http://www.tandfonline.com/doi/abs/10.1080/03066150.2014.918958\#.VeCmsfmqqko. To cite this article: Mamonova, N., \& Visser, O. (2014). State marionettes, phantom organisations or genuine movements? The paradoxical emergence of rural social movements in post-socialist Russia. Journal of Peasant Studies, 41(4), 491-516.

chairman of sovkhoz, called us [employees who were also land and property holders of the enterprise] for a meeting in 1998. He said that there was an investor who wanted to invest in Gorki-2 on the condition that we all invest our shares into the farm enterprise. He promised a beautiful future for us and our children. We used to believe our chairman. However, the will of the shareholders was not registered as required by law. Some of us did not have land-share certificates at that time yet! [...] Nevertheless, the investor acquired our sovkhoz. [...] They [investor in cooperation with the chairman] secretly organised an additional issue of shares, which were bought by the investor. We did not know about that. They forged a number of corporate documents and got full control over Gorki-2 and its lands. Since 2002 they launched bankruptcy proceedings. As a result, agricultural activities were terminated, we were fired, and the largest part the land of Gorki-2 was built up with cottages. [...] For 5,5 years we fought for the restitution of our land rights. I was the leader of the group of 600 deprived shareholders of Gorki-2. It was a difficult fight. During that time I was threatened, chased, they tried to give me a bribe. [...] First, we launched pickets, demonstrations in front of local, regional and federal authorities, wrote petitions to the prosecutor's office, and applied to courts. Authorities knew our problem, but did nothing. [...] Courts passed sentences over and over again not in our favour, although we had documents confirming that it was an illegal acquisition. [...] Then, we found a weak point: Rublevka is the street where many politicians drive daily. For two years we almost did not leave this street. We stood with placards along Rublevka for 2 years 3 days a week from 8 a.m. to 5 p.m. And we kept writing to courts and prosecutors. [...] We received compensation for our lands in 2008. [...] Now we help deprived shareholders from other farm enterprises. Now we are Krestyanski Front. ${ }^{22}$

The contentious politics of Krestyanskiy Front somewhat resembles the 'rightful resistance' in the Chinese countryside, described by O'Brien (1996). However, in contrast with Chinese social movements, Russian legitimate protest is more limited. Under the Chinese regime's dominant (socialist) ideology, appealing to higher authorities when lower authorities misbehave can be an effective strategy. In contemporary Russia, applying to higher authorities is mostly to no avail. It is only occasionally successful, when combined with strong media attention and collective action.

Some actors of other social organisations and authorities are critical of Krestyanskiy Front's methods. In the majority of land disputes, Krestyanskiy Front demands financial compensation for its members, not a restitution of their land rights on the disputed territories. According to a statement by Vasily Vershinin, one of the leaders of the social organisation Agrarii Rossii, Krestyanskiy Front's staffs gets a certain share from the financial compensations their members receive. This raises concerns about the incentives of the Front's operations and its choice of particular sites of land disputes. Valeriy Sarbash, head of the Department of Agriculture and Food Industry of the Dmitrov district in the Moscow region, who was experienced in working with Krestyanskiy Front, criticized its “commercialisation”:

\footnotetext{
22 Interview conducted in October 2010, in Moscow
} 
This is an Accepted Manuscript of an article published by Taylor \& Francis in the Journal of Peasant Studies on 09 Jun 2014, available online: http://www.tandfonline.com/doi/abs/10.1080/03066150.2014.918958\#.VeCmsfmqqko. To cite this article: Mamonova, N., \& Visser, O. (2014). State marionettes, phantom organisations or genuine movements? The paradoxical emergence of rural social movements in post-socialist Russia. Journal of Peasant Studies, 41(4), 491-516.

I don’t respect this organisation because Krestyanskiy Front pursues its own interests. I already understood this last year. They were here [in the Dmitrov district]. They tried to organize something... But those farmers and rural residents who have problems with their land shares, they realized that it is better not to work with Krestyanskiy Front. The land issues cannot be solved in one day. It is better to work with authorities. The Front, you know, has a speculative attitude to these issues. $^{23}$

It is not surprising that representatives of the state dislike the Krestyanskiy Front's approach of mobilizing rural dwellers. Quite the opposite, as the dispossession of small-scale landholders is a process in which the state is seldom free of blame, with authorities either doing next to nothing to prevent it, or possibly being secretly part of the process themselves (there being strong suggestions to the latter). However, it should be stated that in the case of this particular district, there are no indications of an involvement of authorities to the detriment of rural dwellers. The critiques on Krestyanskiy Front by other actors are expressed in a Russian context in which people tend to distrust any political action and tend to assume hidden self-interests behind every form of collective action (Shevchenko 2009).

The money-generation of the Front is important for pursuing its activities (hiring lawyers to represent rural dwellers in courts, providing free consultancy services to deprived land holders, maintaining organisational structure, organizing pickets and demonstrations, etc.) and for guaranteeing its independency from any kind of donors and sponsors. According to McCarthy and Zald (2001, 533), social movements need to generate financial resources to be 'effective, because dissent and grievances alone will not generate social change'. For instance, Brazil's Landless Rural Workers' Movement (MST) actively campaigns to get its representatives elected in senatorial positions in different states, and asks these senators for sponsorship (Vergara-Camus 2009). As long as the generation of financial resources does not become the major goal of the movement, it should not be seen as a contradiction to its goals. However, resource mobilisation could define the methods of the movement, which might influence the outcome. Thus, by asking money instead of land as compensation for their members, Krestyanskiy Front does not fight de-peasantisation in terms of land ownership, which contradicts its goal of preserving the Russian peasantry.

Nevertheless, Krestyanskiy Front can be considered a successful movement. It managed to receive compensation for deprived land-share holders, who are predominantly pensioners and do not intend to cultivate land themselves and are willing to sell it. In comparison with Ukraine, where land dispossession of rural dwellers is similar to Russian circumstances but practically without overt

\footnotetext{
${ }^{23}$ Interview conducted in March 2011, in Dmitrov, the Moscow region.
} 
This is an Accepted Manuscript of an article published by Taylor \& Francis in the Journal of Peasant Studies on 09 Jun 2014, available online: http://www.tandfonline.com/doi/abs/10.1080/03066150.2014.918958\#.VeCmsfmqqko. To cite this article: Mamonova, N., \& Visser, O. (2014). State marionettes, phantom organisations or genuine movements? The paradoxical emergence of rural social movements in post-socialist Russia. Journal of Peasant Studies, 41(4), 491-516.

resistance (Mamonova 2012), the Russian villagers have recently started to participate in open contentious politics, organized by the leaders of Krestyanskiy Front. Of course, on the one hand, this civil engagement could be considered opportunistic rational behaviour as described by Popkin (1979), where the financial compensation for land plots represents the incentive that stimulates Russian rural dwellers to act in a group-oriented way. However, the appearance of overt organized resistance in Russia could also be perceived as an indication of emerging political consciousness among villagers.

\section{Political parties}

One could expect that an increasingly contained political opportunity structure in Russia will lead to more apolitical methods of RSMO campaigning, which is observed in the case of some environmental, disability, or animal rights movements (Fröhlich 2012, Henry 2006, 2010, Chebankova 2012, Kulmala 2011). Counterintuitively, the RSMOs are becoming unduly politicized, as a number of these organisations have set a goal to transform into a political party. Our analysis of the political orientation of RSMOs suggests that this is not a by-product of successful mobilisation, as Walder (2009) states, but that the reverse is the case in today's rural Russia.

This trend could be seen as a shift to the 'new game', first discussed by Henry (2006) in her study of environmental social movement in Russia. Civil organisations have accepted their failure to change the current situation by acting as apolitical associations. Instead, they create political forces as an alternative to the current political regime, in order to 'change the rules of the game themselves, [...] something only possible from inside the political process' (ibid, 120). Many RSMO leaders are of the same opinion. Mikhail Varaksin, member of the association/political party Selskaya Rossiya (Rural Russia), stated:

A social movement or association cannot sufficiently protect the interests of the rural population. It does not have enough force to unite supporters around it; furthermore, it cannot use legislative measures to change the situation. A political party can do this. The party on behalf of rural residents can create laws that reflect the interests of rural citizens. ${ }^{24}$

Social movements with a political orientation predominantly target the state in their claims (McAdam et al. 2003). However, Russian politically-oriented RSMOs fall into state-embedding, and avoid politically sensitive issues such as land grabbing.

After the dissolution of Agrarnaya Partiya Rossii (Agrarian Party of Russia) through its merger with United Russia in 2009, political parties turn their attention to rural issues only to create a favourable impression, and do not undertake any actions to improve the situation. Thus, the liberal party Yabloko

\footnotetext{
${ }^{24}$ Interview conducted in March 2011, in Odintsovo, the Moscow region.
} 
This is an Accepted Manuscript of an article published by Taylor \& Francis in the Journal of Peasant Studies on 09 Jun 2014, available online: http://www.tandfonline.com/doi/abs/10.1080/03066150.2014.918958\#.VeCmsfmqqko. To cite this article: Mamonova, N., \& Visser, O. (2014). State marionettes, phantom organisations or genuine movements? The paradoxical emergence of rural social movements in post-socialist Russia. Journal of Peasant Studies, 41(4), 491-516.

(Apple) was involved in public demonstrations for the rights of rural dwellers, organized by Krestyanskiy Front. However, the description of Yabloko’s participation by Tamara Semenova suggests that its involvement was rather pragmatic. Leaders from Yabloko gave speeches at public meetings with clear visibility, but did not commit to more sustained cooperation. ${ }^{25}$ The leader of the political party Volia (Will), Svetlana Peunova, commented on the attention of political parties for the rural population:

Public support is important to political parties registered in the Russian Federation only during the elections. In reality, none of them is concerned about the problems of the rural population. ${ }^{26}$

Currently, there are only two political parties that aim to represent rural interests: Agrarii Rossii (Agrarians of Russia) and Selskaya Rossiya (Rural Russia). They have arisen from RSMOs, and have not (yet) generated enough votes to obtain seats in the Parliament.

The social organisation Selskaya Rossiya starts its history in 2009. It was established by Sergey Shugayev, a lawyer and chairman of Krestyanskiy Front, who left the Front after its short-time union with the social movement Nasha Zemlia (Our Land). In 2007, Krestyanskiy Front and Nasha Zemlia made an attempt to unite, but they fell apart after the unsuccessful attempt of Krestyanskiy Front to transform into a political party. It is worthy of note that the leader of Nasha Zemlia Dmitry Larionov criticized Krestyanskiy Front for its political ideas:

'Nasha Zemlia believes that the decision of transforming Krestyanskiy Front into a political party is premature, opportunistic and does not match the current state of civil society in Russia' 27.

In 2008, Krestyanskiy Front attempted to form a political party, but failed as it did not receive the required number of signatures and lost the support of Nasha Zemlia, which was its main partner in this endeavour. However, a year later, Larionov became a co-founder of the political social movement Selskaya Rossiya, and now he is one of the leaders of this new party.

This example demonstrates the inability of Russian RSMOs to form coalitions, which decreases the power of the social movement and shrinks the political opportunity structure, according to Tarrow (1998). Henry (2006) explains the difficulties of coalition-building between social organisations in Russia by the fact that their leaders, instead of searching for a consensus, prefer to spin-off and establish movements/political parties that fit their personal political ambitions (ibid, 101, 107). This can explain the huge amount of RSMOs which never passed the stage of 'phantom movements', a trend which will be discussed in the next subsection.

\footnotetext{
25 interview conducted in March 2011, in Moscow

${ }^{26}$ Interview conducted in March 2011, via e-mail.

${ }^{27}$ Interview with Larionov, newspaper Klyuch [Key], March 2008.
} 
This is an Accepted Manuscript of an article published by Taylor \& Francis in the Journal of Peasant Studies on 09 Jun 2014, available online: http://www.tandfonline.com/doi/abs/10.1080/03066150.2014.918958\#.VeCmsfmqqko. To cite this article: Mamonova, N., \& Visser, O. (2014). State marionettes, phantom organisations or genuine movements? The paradoxical emergence of rural social movements in post-socialist Russia. Journal of Peasant Studies, 41(4), 491-516.

Analysing the activities of Selskaya Rossiya, we can argue that it resembles an interest group ${ }^{28}$ more than a political party. Its membership consists of entrepreneurs operating in the Russian agricultural sector. The party pursues propaganda for a rural lifestyle and provides information support to its members. The expenses of the party are covered by revenues from entrepreneurial activities and the personal contributions of its leaders. The party acts as a mediator between producers, traders, and consumers of agricultural products. Thus, businessman Mikhail Varaksin, head of the party's Moscow region office, joined the party in search of new distribution channels and new business partnerships for his agricultural company: ' ...through the membership in the party, I found new regional contacts for the supply of my products'. ${ }^{29}$

The second active rural political party is Agrarii Rossii. It was established in 2002, and does not generate revenues itself, but relies on donations from its leaders and other interested parties. It is organized by experienced political activists and former members of Agrarnaya Partiya Rossii who did not agree with the take-over by United Russia. Initially, Agrarii Rossii focused on the rural and urban populations, had a socialist ideology, and openly disagreed with the politics of United Russia. Therefore, their activities were limited by political, legal and economic constraints. In 2011, while this RSMO was being transformed into a political party, one of its leaders, Vasily Vershinin, commented on their chances to get into politics:

The chance is very small. I give it a three to five percent chance that we will be able to register as a party. They [United Russia] will not let us. These days we have parties that are not what people want. That is all about the current government: if they allow it or not... ${ }^{30}$

During the presidential election of 2012, Agrarii Rossii experienced the fate of its predecessor Agrarnaya Partiya Rossii. It radically changed its political orientation from socialist to pro-United Russia, and a rural appeal: 'Vote for Putin!' was adopted during its official assembly in February 2012. ${ }^{31}$ This transformation allowed the organisation to enter Russian political circles, but at the cost of its autonomy in policy and programme.

Therefore, contemporary agrarian political parties suffer from state-embedding and lack of autonomy in their programmes. The politicisation of RSMOs does not lead to formations of political forces as an alternative to the current political regime, but creates 'state marionettes' that unconditionally follow the instructions of the ruling party and do not represent a political force that can make changes.

\footnotetext{
${ }^{28}$ An interest groups is virtually any voluntary association that seeks to publicly promote and create advantages for its cause. For more information about the differences between social movements and interest groups see Meyer and Imig (1993)

${ }^{29}$ Interview conducted March 2011, in Odintsovo, the Moscow region.

${ }^{30}$ Interview conducted: March 2011, in Moscow.

${ }^{31}$ Information from the website of Agrarii Rossii, accessed 15 December 2012
} 
This is an Accepted Manuscript of an article published by Taylor \& Francis in the Journal of Peasant Studies on 09 Jun 2014, available online: http://www.tandfonline.com/doi/abs/10.1080/03066150.2014.918958\#.VeCmsfmqqko. To cite this article: Mamonova, N., \& Visser, O. (2014). State marionettes, phantom organisations or genuine movements? The paradoxical emergence of rural social movements in post-socialist Russia. Journal of Peasant Studies, 41(4), 491-516.

\section{Phantom movement organisations}

Phantom movement organisations are understood here as non-transparent, at most occasionally-active social organisations that pursue goals often different from the ones officially declared, in particular pursuing the aims of umbrella organisations and/or the leaders' personal aims instead of defending the interests of their declared constituencies. These movements have similarities with Latin-American ambivalent organisations studied by Junge (2012) and Edelman (1999).

The appearance of 'shadow pseudopublics', described by Junge in his study of grassroots communities and NGOs in Brazil, resembles the Russian case. Junge (2012, 407) argued that the changing relationship between state, private sector, and civil society has contributed to the destabilisation of the narrative of active citizenship hegemony in earlier years, implanting a market-oriented, individualistic ethos in its place'. Junge's concept of 'shadow pseudopublics' i.e. civil organisations acting as fronts for a 'secretive, undemocratic, and non-transparent source of power' (ibid, 407) can be applicable to Russian rural civil society.

The non-transparency of many Russian RSMOs leads in some cases to their use as an umbrella for "tertiary" goals. The scandal around the land of the Borodinskoe Pole Museum-Reserve in the Borodino village, Mozhaysk district, received wide publicity in 2010-2012. The reason for this was not only the 11,000 hectares of historical land that were partly illegally converted in construction sites $^{32}$, but also the fact that Valeriy Myaukin, head of the Public Council for the Conservation of Historical and Cultural Heritage of the Mozhaisk district, was the one who organized the illegal construction. The director of the museum, Alexander Gorbunov, who has been fighting against the acquisition of the museum's lands, stated about Myaukin's organisation:

...the Public Council exists only on paper and its head, Myaukin, uses the council's networks and credentials to transform the Borodino lands into cottage construction. ${ }^{33}$

Apart from leading this Public Council, Valeriy Myaukin is an agro-businessman, chairman of the agricultural committee of the Mozhaysk district, and a member of United Russia. The contacts with

\footnotetext{
32 During the 2010-2012 period, an illegal development was underway at the Borodino museum reserve, where the Russian army fought Napoleon's troops in 1812. This area is considered national heritage by Russians. The boundaries of the Borodino reserve have never been officially defined or registered due to lack of funds. This has also enabled corrupt officials to manipulate this "no man's land.” 100 private houses were being built on the Field of Borodino, a federal-level historical reserve, despite the continued efforts of law enforcement bodies, let alone culture protection agencies (Visser and Mamonova 2011). In 2013, the court considered two criminal cases against the former head of the Borodino rural settlement, Maya Sklyueva. According to investigators, Sklyueva had been taking advantage of her official position and using forged documents from January 2007 to March 2008. She acquired the land area in the field of Borodino from the area towns Kosmovo and Old Village. Sklyueva is condemned to five years and six months imprisonment. The houses will be demolished.
}

${ }^{33}$ Interview conducted March 2011, in Borodino, the Mozhaysk district, the Moscow region. 
This is an Accepted Manuscript of an article published by Taylor \& Francis in the Journal of Peasant Studies on 09 Jun 2014, available online: http://www.tandfonline.com/doi/abs/10.1080/03066150.2014.918958\#.VeCmsfmqqko. To cite this article: Mamonova, N., \& Visser, O. (2014). State marionettes, phantom organisations or genuine movements? The paradoxical emergence of rural social movements in post-socialist Russia. Journal of Peasant Studies, 41(4), 491-516.

power-holders and the access to information about the museum's landholdings made him a very strategically positioned person to pursue land grabbing on the territory of the Borodino museum.

Remarkably, when several criminal cases were launched against the illegal constructions on Borodino lands in 2013, Myaukin did not appear in any of them. The head of the local administration, Maya Skluyeva, was imprisoned for 5 years for machinations regarding the historical lands. According to Sergey Kuznets, the head of social movement Komitet po Naslediyu (Committee on Heritage) in the Sergiev-Posad district:

The imprisonment of Skluyeva was just a farce. They needed to find the "scapegoat" in order to calm down the society. Skluyeva was, of course, engage in this fraud, but there were much larger fish... ${ }^{34}$

Phantom movement organisations appear in the authoritarian regime as a by-product of political party formation. The director of the Russian branch of the International Centre for Non-Commercial Law, Darya Miloslavskaya, stated that:

Russian politicians create social movements because they cannot fulfil the conditions of the Ministry of Justice on the minimum number of members requested for political party registration. ${ }^{35}$

As a consequence, many phantom movement organisations emerge within the contemporary rural social movement. Some of these are created with the aim of later transformation into political parties, but are not successful and become what can probably be characterized as 'imagined organisations' (Edelman 1999). Edelman describes examples in Costa Rica less critically than Junge's concept of 'shadow pseudopublics', however, the idea of the ambiguity and ambivalence is similar. According to Edelman (1999), imagined organisations exist primarily in the minds of their leadership and donors, and can 'undergo metamorphoses that lead to their re-emergence and reinsertion in a vital and genuine political practice’ (ibid, 5). Among such RSMOs we distinguish Agrarnaya Rossiya (Agrarian Russia) and Narodniy Front v Zaschitu Russkoy Zemli (National Front for Russian Land Protection), both of which arose and faded during the last decade, and which may arise again if their leaders need to engage in rural politics.

Phantom movement organisations are often linked with parent-organisations, which use/used to prove the accomplishment of proclaimed goals. For example, AKKOR proclaimed the protection of agrarian women's rights, and therefore established Dvizhenie Selskih Zhenschin Rossii (Movement of Rural Women in Russia). Using the financial sources of its parent-organisation, the movement does not go further than participating in conferences, mainly organized by AKKOR. Another example of

\footnotetext{
${ }^{34}$ Interview conducted April 2013, in Sergiev Posad, the Moscow region.

35 From interview to newspaper Kommersant, March 2011.
} 
This is an Accepted Manuscript of an article published by Taylor \& Francis in the Journal of Peasant Studies on 09 Jun 2014, available online: http://www.tandfonline.com/doi/abs/10.1080/03066150.2014.918958\#.VeCmsfmqqko. To cite this article: Mamonova, N., \& Visser, O. (2014). State marionettes, phantom organisations or genuine movements? The paradoxical emergence of rural social movements in post-socialist Russia. Journal of Peasant Studies, 41(4), 491-516.

such organisations is Molodezhnoe Krilo Partii Agrarii Rossii (Youth Wing of the party Agrarii Rossii). It was organised by the political party Agrarii Rossii, which declared its support to young people in rural areas. The Wing does not operate in practice, but the goal to engage young rural dwellers into political life is formally accomplished.

The existence of various phantom movement organisations in Russia demonstrates that the current political regime does not allow for sufficient space for civil and political activism. The state control over civil society organisations generally leads to the stagnation of local initiatives, and the appearance of pseudo-organisations of powerful elites.

\section{Conclusions}

We addressed the question of why rural social movement organisations (RSMOs) in Russia have been so weak. From narrow, liberal, and statist views of state-society relations, it is tempting to see the (increasingly) repressive regime as the overarching determinant. However, on closer inspection, this cannot be the sole, overarching argument for various reasons. If we look more closely at the periodisation of the emergence of social movements in Russia, we see that the early post-soviet period, which was characterised by the democratisation of society and deep rural poverty, did not generate significant 'open moments' for political group actions, as some expected (Gourevitsch 1986). Just a few, rather top-down, civil society organisations dealt with rural issues at that time. Among the factors that muted potential for collective political action, we have discussed the continued dependence of rural dwellers on their subsidiary household plots, and the demography of rural society.

Contrary to the calm of the early post-soviet period, the emergence of RSMOs occurred in the last decade, when the political space for contestations became heavily constrained by the Putin government.

We explained the (partially virtual) burst of RSMOs by the growing insecurity that villagers confront regarding their land rights, along with booming land investment and land speculation by Russian elites. This argument is in line with the deprivation thesis. Moreover, the mobilisation of rural dwellers for such a bread-and-butter issue as defending their land (and property) rights is easier in Russia than generating support among the population for more abstract issues such as food sovereignty, food imports, environmental protection, organic farming, or a peasant lifestyle, which have been the basis of mobilization of rural dwellers in other countries (e.g. Evans 2012).

Second, the state's attention to agriculture has increased (although still being at a low level). During the late 1990s and early 2000s, the countryside more or less disappeared from the political agenda, as 
This is an Accepted Manuscript of an article published by Taylor \& Francis in the Journal of Peasant Studies on 09 Jun 2014, available online: http://www.tandfonline.com/doi/abs/10.1080/03066150.2014.918958\#.VeCmsfmqqko. To cite this article: Mamonova, N., \& Visser, O. (2014). State marionettes, phantom organisations or genuine movements? The paradoxical emergence of rural social movements in post-socialist Russia. Journal of Peasant Studies, 41(4), 491-516.

reflected for instance by the disappearance of the Agrarian Party. Since Putin came to power, political attention started to rise, spurred by the increased economic importance of the sector. With the growing economic importance of agriculture, the State had an incentive to become more involved in influencing or establishing RSMOs as a way to control rural society.

Third, from an interest groups perspective, an important factor is that, with the recovery of the agriculture and state subsidies and private money entering the sector, it became more attractive for different actors to establish (or join) RSMOs in order to gain benefits from agricultural and rural development projects and emerging businesses. The appearance of numerous phantom movement organisations and politically-oriented RSMOs is rather difficult to explain, whether starting from their constituency's needs or from the stated aims in the organisations' statutes. However, the rise of RSMOs becomes less paradoxical once one approaches it from the angle of the narrow personal interests of their leadership.

The next major question this paper dealt with was the character of RSMOs in Russia and how genuine they are. Are they state marionettes, counterfeits, or genuine movements? This question of genuineness touches upon several dimensions: their constituency (the link with the population); the degree of their independence (the relation with the state); and actual performance (the execution of their statutory objectives or other, hidden goals).

In answering these questions, it was necessary to distinguish between various types of RSMOs. We have shown that there is a wide diversity of RSMOs (government affiliates, professionalised movements, politically oriented organisations, phantom organisations, and grassroots movements), with a rather limited cooperation between them.

The grassroots RSMOs are characterised by the highest autonomy from the state and the closest ties with the rural population. The bottom-up emergence of these RSMOs and the bread-and-butter issues they are dealing with allow them to mobilise villagers for open collective protest (against land grabbing, as in the case of Krestyanskiy Front). At the same time, the relative independence from the state restricts political space for their activities, and limits their access to necessary resources (fund raising possibilities, participation in state rural development programmes, informational support). Therefore, these RSMOs have to search for alternative ways to mobilise resources. The issue of raising money for RSMOs activities is very sensitive in a Russian context in which people tend to distrust any political action and assume hidden self-interests behind every form of collective action. ${ }^{36}$ The grassroots RSMOs often act within the legal framework. They innovatively use laws, policies, and

\footnotetext{
${ }^{36}$ At the same time, taking into account the political indifference of rural dwellers, providing individual economic rewards to staff and participants is perhaps the only method to involve people in social movement activity.
} 
This is an Accepted Manuscript of an article published by Taylor \& Francis in the Journal of Peasant Studies on 09 Jun 2014, available online: http://www.tandfonline.com/doi/abs/10.1080/03066150.2014.918958\#.VeCmsfmqqko. To cite this article: Mamonova, N., \& Visser, O. (2014). State marionettes, phantom organisations or genuine movements? The paradoxical emergence of rural social movements in post-socialist Russia. Journal of Peasant Studies, 41(4), 491-516.

other officially promoted values to defend the rights of their members and attack disloyal authorities and elites. In this sense, there is some resemblance with the Chinese 'legitimate protest' as conceptualised by O’Brien (1996). However, the political opportunity structure in Russia is more restricted than in rural China. The understanding of protest in Russia and, more broadly, post-socialist and semi-authoritarian settings, would benefit from future research on how protest in these contexts resembles and deviates from 'legitimate protest'. ${ }^{37}$

On the other end of the spectrum are the phantom movement organisations (opposite to grassroots RSMOs in terms of activeness) and state-oriented RSMOs such as the politically oriented organisations, professional organisations, and of course, government affiliates (opposite to grassroots RSMOs in terms of independence).

The existence of phantom movement organisations in Russia reflects the state policy of constraining the room for civil and political action. The state control leads to stagnation or shadowing in many local initiatives, and the appearance of pseudo-organisations set up by powerful elites. According to Edelman (1999, 5), despite the ambiguity and ambivalence of imagined organisations, they can be 'sometimes those with the deepest and most selfless commitments to fundamental change and the greatest capacities for envisioning creative solutions to profound development dilemmas'. So far, there is little evidence that phantom movements are able to generate such creative solutions. In various cases, it seems that they are meant to be only an umbrella for "tertiary" goals.

It might be tempting to see grassroots RSMOs as the only genuine movements, but according to some Russian scholars (e.g. Vorobjev 2009) the more state-oriented organizations correspond more with the population's ideas on civil society; they should, therefore certainly be classified as part of the civil society, and perhaps even be seen as the genuine movements in Russia. We do not take sides here, but instead argue that there is no one genuine type of movement/organisation. Moreover, it is important not to discard movements with strong state embeddedness too quickly as co-opted. Recent studies on Russian movements (Abers 2000, Dagnino 2002, Henderson 2011) have argued that social movement organisations can be more efficient if they collaborate with the state, while keeping space to protest. Those RSMOs, which are close to the state, are able to lobby the interests of their members and gain necessary resources for their activities (as in the case of AKKOR). However, we do not observe a significant struggle of the state-embedded organisations to represent the interests of rural dwellers outside the state legalised spaces. Any attempts to oppose the state openly and directly have been

\footnotetext{
37 'In the most repressive regimes, resistance is largely limited to the "weapons of the weak"', according to O'Brien (1996, 47). We do not want to suggest that this is the case in Russia. There are various important differences from the rural protest in China, such as the lack of a clear overarching state ideology that would enable the framing protest in legitimate terms, and the achievement of gradual, but fundamental changes in the system. These issues, which go beyond the scope of this paper, are planned to make the subject of another publication.
} 
This is an Accepted Manuscript of an article published by Taylor \& Francis in the Journal of Peasant Studies on 09 Jun 2014, available online: http://www.tandfonline.com/doi/abs/10.1080/03066150.2014.918958\#.VeCmsfmqqko. To cite this article: Mamonova, N., \& Visser, O. (2014). State marionettes, phantom organisations or genuine movements? The paradoxical emergence of rural social movements in post-socialist Russia. Journal of Peasant Studies, 41(4), 491-516.

suppressed until now (as in the case of Agrarii Rossii). This brings to mind the formation of 'state marionettes'.

However, more productive than applying such labels as 'state marionettes' is to attempt to analyse why these state embedded RSMOs have not engaged in social and political struggles. ${ }^{38}$ With the emergence of the RSMOs being such a new phenomenon, and as this article is the first study on the topic, we can only indicate a few factors that play a role and need further study. The first reason seems to be the power (or rather the lack of it) of the rural population in society. During the past few years, protests in large cities have grown in number (Evans 2010). The government tries to channel such discontent into arenas it can control to some extent. To give such initiatives legitimacy and attractiveness, the regime has to provide some room for voicing alternative views. With the rural population generally less economically significant, less politically engaged, and more supportive of the regime, the government would feel less of a need to give leeway to such organisations. Second, RSMOs are rather young (except from AKKOR) and, therefore, they might yet to have found the room to voice discontent and strategies of operation.

Whatever the exact reason for the strong state embeddedness and lack of independence of RSMOs, these organisations pay a high price for it. The state affiliates experience a rupture in the already precarious relations with the rural population (most aptly illustrated by the case of AKKOR). The tendency of state affiliates to drift away from their constituency and the existence of phantom movement organisations are likely to reinforce beliefs among the population that social movement organisations cannot be trusted, and that the leaders only follow their own political or economic interests.

Thus, overall, the contemporary RSMOs in Russia face a wide range of challenges, among which their limited political space, fragmentation, often counterfeit or state-dependent character, and most crucially, a weak link with the rural population. Nevertheless, some of them constitute genuine movements, in a rural setting where less than a decade ago they had been absent.

\footnotetext{
${ }^{38}$ It is good to recognise that 'state marionettes' are not just present in semi-authoritarian regimes and/or a sign of weak civil society. In the Netherlands, for instance, the country's communist party was established during the Cold War by the Dutch secret service to enable the monitoring and control of communist forces in society.
} 
This is an Accepted Manuscript of an article published by Taylor \& Francis in the Journal of Peasant Studies on 09 Jun 2014, available online: http://www.tandfonline.com/doi/abs/10.1080/03066150.2014.918958\#.VeCmsfmqqko. To cite this article: Mamonova, N., \& Visser, O. (2014). State marionettes, phantom organisations or genuine movements? The paradoxical emergence of rural social movements in post-socialist Russia. Journal of Peasant Studies, 41(4), 491-516.

\section{References:}

Abers, R.N. 2000. Inventing local democracy: grassroots politics in Brazil. London: Lynne Rienner Publishers.

Atkinson, D. 1983. The End of the Russian Land Commune, 1905-1930. Stanford, CA: Stanford University Press.

Auritzer, L. and B. Wampler. 2004. Participatory publics: civil society and new institutions in democratic Brazil. Comparative Politics, 36(3), 291-312.

Breshko-Breshkovskaya, E. 2006. Hidden roots of the Russian Revolution. Renunciation great revolutionary. 1873-1920 Moscow: Tsentrpoligraf.

Chebankova, E. 2012. State-sponsored civic associations in Russia: systemic integration or the 'war of position'? East European Politics, 28(4), 37-41.

Dagnino, E. 2002. Sociedade Civil e Espacos Publicos no Brazil. Sao Paulo: Paz e Terra.

Dagnino, E., Olvera, A.J., and A. Panfichi, eds. 2006. A disputa pela construcao democratica na America Latina. Sao Paulo: Paz e Terra.

Duacé, F. 2010. Activists in the Trap of Anti-Politics: An Exploration of the Powerlessness of Human Rights NGOs in Russia. Laboratorium, 2(2), 86-102.

Edelman, M. 1999. Peasants Against Globalisation: Rural Social Movements in Costa Rica. Stanford: Stanford U.P.

Evans, Ag.B.Jr. 2012. Protests and civil society in Russia: The struggle for the Khimki forest. Communist and Post-Communist Studies, 45, 233-242.

Fröhlich, C. 2012. Civil society and the state intertwined: the case of disability NGOs in Russia. East European Politics, 28(4), 37-41.

Goodman, D. 2003. The Quality Turn and Alternative Food Practices: Reflections and Agenda, Journal of Rural Studies, 19: 1-7.

Gourevitch, P. 1986. Politics in Hard Times. Ithaca, NY: Cornell University Press.

Hale, H. 2002. Civil Society from Above? Statist and Liberal Models of State-Building in Russia. Demokratizatsiya, 10 (3), 306-321.

Henry, L. 2010. Between transnationalism and state power: the development of Russia's post-Soviet environmental movement. Environmental Politics, 19(5), 756-781.

Henry, L.A. 2006. Shaping Social Activism in Post-Soviet Russia: Leadership, Organizational Diversity, and Innovation. Post-Soviet Affairs, 22(2), 99-124.

Humphrey C. 1983. Karl Marx Collective: Economy, Society and Religion in a Siberian Collective Farm. Cambridge: Cambridge University Press.

Humphrey, C. 2002. Subsistence farming and the peasantry as an idea in contemporary Russia. In: P. Leonard and D. Kaneff eds. Post Socialist Peasant? New York: Palgrave.

Independent Institute for Social Policy. 2002. Inequality and Poverty in Russia in Transition. Availailable from: http://www.socpol.ru/eng/research_projects/pdf/proj10a.pdf [Accessed on 10 September 2013].

Janoski, T. 1998. Citizenship and Civil Society. A Framework of Rights and Obligations in Liberal, Traditional, and Social Democratic Regimes. Cambridge: Cambridge University Press. 
This is an Accepted Manuscript of an article published by Taylor \& Francis in the Journal of Peasant Studies on 09 Jun 2014, available online: http://www.tandfonline.com/doi/abs/10.1080/03066150.2014.918958\#.VeCmsfmqqko. To cite this article: Mamonova, N., \& Visser, O. (2014). State marionettes, phantom organisations or genuine movements? The paradoxical emergence of rural social movements in post-socialist Russia. Journal of Peasant Studies, 41(4), 491-516.

Junge, B. 2012. NGOs as shadow pseudopublics: Grassroots community leaders' perceptions of change and continuity in Porto Alegre, Brazil. American Ethnologist 39 (2), 407-424.

Kopoteva, I. 2012. Civil society and associations in Russian Karelia. In: Alanen, I., Nikula, J. and L. Granberg, eds. Traces of peasantry and post-socialism Researching realities. Tampereen: Juvenes Print.

Kröger, M. 2011. Promotion of contentious agency as a rewarding movement strategy: evidence from the MST-paper industry conflicts in Brazil. Journal of Peasant Studies, 38(2), 435-458.

Kulmala, K. 2011. Russian State and Civil Society in Interaction: An Ethnographic Approach. Russian Review of Social Research, (1), 51-83.

Makarkin, A. 2004. Agrarian Party of Russia. Otechestvenniye Zapiski, 1. Available from: http://magazines.russ.ru/oz/2004/1/2004_1-1_28.html [Accessed 24 September 2013].

Male, D.J. 1971. Russian Peasant Organisation before Collectivisation: A Study of Commune and Gathering 1925-1930. Cambridge: Cambridge University Press.

Mamonova, N. 2012. Challenging the dominant assumptions about peasants' responses to land grabbing. A study of diverse political reactions from below on the example of Ukraine. Paper presented at the International Conference on Global Land Grabbing II. Cornell University, 17-19 October 2012.

McAdam, D., Tarrow, S. and C. Tilly. 2003. Dynamics of Contention, Social Movement Studies. Journal of Social, Cultural and Political Protest, 2(1), 99-102

McCarthy, J. and M.N. Zald. 2001. The Enduring Vitality of the Resource Mobilisation Theory of Social Movements. In: J.H. Turner eds. Handbook of Sociological Theory. New York: Kluwer.

Meyer, D. 2004. Protest and political opportunities. Annual Review of Sociology, 30, 125-145.

Meyer, D. S., and D. R. Imig. 1993. Political opportunity and the rise and decline of interest group sectors. The Social Science Journal, 30(3), 253-270.

Nikulin, A. 2003. The Kuban Kolkhoz between a Holding and a Hacienda. Contradictions of Post-Soviet Rural Development. Focaal: Journal of Global and Historical Anthropology, 41, 137-152.

Nikulin, A. 2010. Oligarkhoz kak preemnik postkolkhoza. Ekonomischeskaya Sotsiologiya, 11(1), 17-33.

Nove, A. 1973. Efficiency Criteria for Nationalised Industries. London: Allen and Unwin.

O’Brien, D.J., Patsiorkovski, V.V., and L.D. Dershem. 2000. Household Capital and the Agrarian Problem in Russia. Sydney: Ashgate.

O'Brien, K. 1996, Rightful Resistance. World Politics, 49 (1), 31-55.

Osokina, I. 2009. Ot SSSR k RF: Koordinalnie izmeneniya v ekonomike i politike (From the USSR to Russia: the dramatic changes in the economy and politics). Available from: http://www.historicus.ru/ot_sssr_k_rf/ [Accessed 2 December 2012].

Ostroukh, A. 2012. Russia's Putin signs NGO 'foreign agents' law. Available from: http://www.reuters.com/article/2012/07/21/us-russia-putin-ngos-idUSBRE86K05M20120721 [Accessed 23 September 2013].

Panchenko, A., Matrosov, A., and I. Solomka. 2012. Ukrainian peasants': we plow before dawn, and we do not see any money. Rumors about the prosperity of the Ukrainian village because of rising food prices are exaggerated. Available from: http://m.segodnya.ua/ukraine/ukrainckie-celjane-pashem-dozari-a-deneh-ne-vidim.html [Accessed 07 October 2012].

Perrie, M. 1972. The Russian Peasant Movement of 1905-1907: Its Social Composition And Revolutionary Significance. Past and Present, 57(1), 123-155. 
This is an Accepted Manuscript of an article published by Taylor \& Francis in the Journal of Peasant Studies on 09 Jun 2014, available online: http://www.tandfonline.com/doi/abs/10.1080/03066150.2014.918958\#.VeCmsfmqqko. To cite this article: Mamonova, N., \& Visser, O. (2014). State marionettes, phantom organisations or genuine movements? The paradoxical emergence of rural social movements in post-socialist Russia. Journal of Peasant Studies, 41(4), 491-516.

Politgazeta 2012. Gubernator Gardeev reshil prekratit mitingi odnim mahom. [Gordeev governor decided to stop rallies in one fell swoop] Available from: http://xn--80aahjjduxi7ae.xn--p1ai/2011-05-01-1953-58/item/1874-губернатор-гордеев-решил-прекратить-митинги-одним-махом [Accessed 3 December 2012].

Popkin, S.L. 1979 The Rational Peasant: The Political Economy of Rural Society in Vietnam. Berkeley: University of California Press.

Richter, J. 2009. The Ministry of Civil Society?. Problems of Post-Communism,56(6), 7-20.

Ries, N. 2009. Potato Ontology: Surviving Post-Socialism in Russia. Cultural Anthropology, 24(2), 181212

Rosstat. 2013. Demography. Available from: http://www.gks.ru/wps/wcm/connect/rosstat_main/rosstat/ru/statistics/population/demography/ [Accessed 22 September 2013].

Salamon, L. and H. Anheier. 1998. Social Origins of Civil Society: Explaining Nonprofit Sector CrossNationally. Voluntas, 9(3), 213-248.

Sanukov, X. 1993. Human rights problems in Russia: the situation of non-Russian peoples. Available from: http://www.suri.ee/kongress/sanukov.html [Accessed 1 September 2011].

Scott, J.C. 1985. Weapons of the Weak: Everyday Forms of Peasant Resistance. New Haven: Yale University Press.

Shagaida, N. 2012. Budget Spending and Government Support for Agriculture: Approaches and Evaluation. Paper presented at the seminar Estimation of Budget Spending and Government Support for Agriculture, Laboratory of Agricultural Policy of the Gaidar Institute, 15 October, Moscow, Russia.

Spoor, M., Visser, O. and N. Mamonova. 2012. Russian Agroholdings, Financial Capital and Landgrabbing: Is Russian the new global breadbasket? Paper presented at the IAMO Forum 2012, 22 June, Halle, Germany.

Tarrow, S. 1998 . Power in Movement. New York: Cambridge University Press.

Tarrow, S. 1998. Fishnets, Internets, and Catnets: Globalization and transnational collective action. Challenging authority: The historical study of contentious politics, 228-244.

Tauger, M. 2005. Soviet Peasants and Collectivisation, 1930-39: Resistance and Adaptation. In: S. Wegren eds. Rural Adaptation in Russia. New York: Routledge.

Taylor, V. 1989. Social Movement Continuity: The Women's Movement in Abeyance. American Sociological Review, 54(5), 761-775.

Tysiachniouk, M. 2010. Social Movements for the Preservation of Forests in North-West Russia: From Consumer Boycotts to Fostering Forest Certifications. Russian Analytical Digest, 79, 20-23.

Vergara-Camus, L. 2009. The Politics of the MST: Autonomous Rural Communities, the State, and Electoral Politics. Latin American Perspectives, 36 (4), 178-191.

Visser, O. 2010. Insecure Land Rights, Obstacles to Family Farming and the Weakness of Protest in Rural Russia. Laboratorium, 2(2), 275-95

Visser, O. and M. Spoor. 2011. Land grabbing in post-Soviet Eurasia: the world's largest agricultural land reserves at stake. Journal of Peasants Studies, 38 (2), 299 - 323.

Visser, O., Mamonova, N. and M. Spoor, 2012. Oligarchs , megafarms and land reserves: understanding land grabbing in Russia. Journal of Peasant Studies, 39(3-4), 899-931. 
This is an Accepted Manuscript of an article published by Taylor \& Francis in the Journal of Peasant Studies on 09 Jun 2014, available online: http://www.tandfonline.com/doi/abs/10.1080/03066150.2014.918958\#.VeCmsfmqqko. To cite this article: Mamonova, N., \& Visser, O. (2014). State marionettes, phantom organisations or genuine movements? The paradoxical emergence of rural social movements in post-socialist Russia. Journal of Peasant Studies, 41(4), 491-516.

Vorobjev, S. 2009. Grazhdanskoe oshchestvo I modernizatsiya Rossii. Vlast', 5, 18-21.

Walder, A. 2009. Political Sociology and Social Movements. The Annual Review of Sociology, 35, 393412.

Wegren, S. 2005. Rural Adaptation in Russia. London: Routledge.

Wegren, S. 2007. The State and Agrarian Reform in Post-communist Russia. Journal of Peasant Studies, 34(3-4), 498-526

White, B., Borras Jr, S. M., Hall, R., Scoones, I., and W. Wolford. 2012. The new enclosures: Critical perspectives on corporate land deals. Journal of Peasant Studies, 39(3-4), 619-647.

Woods, M. 2008. Social movements and rural politics. Journal of Rural Studies, 24(2), 129-13.

Yermolayeva, V. 2010. Economic Geography and Regional Studies: a Tutorial. Moscow: Flinta Science.

Zald, M.N. and J.D. McCarthy, eds. 1987. Social Movements in an Organizational Society. New Brunswick: Transaction Books. 